УДК 686.862.3(045)

T.M. АРТЮX

Київський національний університет імені Тараса Шевченка

A.C. ТЕРНОВА

Вінницький торговельно-економічний інститут Київського національного торговельно-економічного університету

I.В. ГРИГОРЕНКО

Націннальний авіаційний університет

\title{
ТОВАРОЗНАВЧА ЕКСПЕРТИЗА МЕХАНІЧНИХ ОЛІВЦІВ
}

\author{
T. ARTYUKH \\ Kyiv National Taras Shevchenko University \\ A. TERNOVA \\ Vinnitsia Trade and Economic Institute of \\ Kyiv National Trade and Economic University \\ I. HRYHORENKO \\ National Aviation University
}

\section{COMMODITY EXAMINATION OF THE MECHANICAL PENCILS}

\author{
https://doi.org/10.36910/6775-2310-5283-2021-14-13
}

Мета. Розробка процедури здійснення товарознавчої експертизи механічних олівців.

Методика. Для експертизи механічних олівців використовувались органолептичні, інструментальні й експертні методи.

Результати. Аналіз експортно-імпортних операцій механічних олівців показує, щуо Украӥна здійснює їх реекспорт: у 2019-2020 роках найбільше даних товарів відправлялося у такі країни СНД, як Російська Федераџія (59,6 та 64,3 \% відповідно по роках), Республіка Молдова (18,3 та 18,6\%), Білорусь (11,9 та 7,1\%).

Вся досліджувана продукиія надходила в основному з Китаю (74,5\% у 2019 роияі та 60,2 - у 2020). У 2019 рочі механічні олівиі надходили також з Японії (10,9\%), Німеччини (5,0), Швейцарії (3,2), Словаччини $(1,8)$ та Чехії (1,5\%). У 2020 рочі їх також найбільше постачала Японія та Німеччина (18,3 та 10,4\% відповідно).

Процедура здійснення товарознавчої експертизи механічних олівців включала такі етапи, як визначення мети, вибір критеріїв, визначення засобів, вибір методів.

Об'єктами товарознавчої експертизи було обрано 5 зразків механічних олівиів найпоширеніших торгових марок: зразок № 1 - механічний олівець торгової марки «РILOT»; зразок № 2 - механічний олівець торгової марки «BRAUBERG»; зразок № 3 - механічний 
олівещь торгової марки «BIC»; зразок № 4 - механічний олівещь «ERICH KRAUSE»; зразок № 5 - механічний олівецьь «FABER CASTELL».

Відповідно до поставлених завдань досліджувались показники: органолептичні (зовнішній вигляд) та механічні (зусилля утримування стрижня механізмом олівия від зсуву; зусилля утримування стрижня механізмом олівия від випадання; висування стрижня під дією власної ваги; величину подачі пишучого стрижня; відсутність зазору між металевим утримувачем і кришкою; міиність на вигин; якість клейових з'єднань корпусних деталей; встановлений ресурс олівия і утримувача).

Усі досліджувані показники якості зразків механічних олівиів відповідають встановленим нормативам.

Практична значимість результатів дослідження полягає у розробиі критеріїв, засобів й методів товарознавчої експертизи механічних олівців, які можна використовувати в роботі підприємств.

Ключові слова: олівець, механічні олівиі, експортно-імпортні операції, реекспорт, експертиза, товарознавча експертиза, процедура, критерії, засоби і методи товарознавчої експертизи.

Постановка проблеми у загальному вигляді і їі зв'язок $з$ важливими науковими та практичними завданнями. Незважаючи на існуючу державну систему контролю якості, безпеки товарів і захисту прав споживачів, внаслідок розбалансування економіки відбувається припинення або суттєве зниження обсягів їх виробництва, а в той же час ринок насичується низькоякісними $\mathrm{i}$ недоброякісними товарами. Для об'єктивного оцінювання якості вітчизняних i імпортних товарів необхідні спеціалізовані організації з експертизи товарів, які можуть зробити компетентний висновок про якість партії товарів, які закуповуються, визначити їх вартість, походження, конкурентоспроможність тощо.

Аналіз останніх досліджень, у яких започатковано вирішення проблеми. Проблемами експертизи непродовольчих товарів займалось чимало вітчизняних науковців. Серед них такі вчені, як Л. Байдакова, С. Ягелюк [1]; М. Зубков, Н. Янченко [2]; А. Мохненко [3]; Н. Осипенко, Т. Писаренко [4]; А. Тернова, С. Сіренко [5]; Н. Хлєбнікова [6]; Ю. Ющенко [7] та багато інших.

Вказані дослідники вивчали загальні питання товарознавчої експертизи товарів. Так, Н. Осипенко, Т. Писаренко досліджували проблеми експертної діяльності в сучасних умовах. Л. Байдакова, С. Ягелюк запропонували комплексну блок-схему проведення експертизи якості непродовольчих товарів. М. Зубков, Н. Янченко, Н. Хлєбнікова вивчали застосування експертних методів у дослідженні непродовольчих товарів. А. Мохненко, Ю. Ющенко 
займалися питаннями інформаційного та інформаційно-аналітичного забезпечення експертизи товарів.

Крім того, багато науковців вивчали особливості експертизи окремих груп непродовольчих товарів. Зокрема, С. Даниленко, О. Кириченко, К. Линник, Н.Лисенко, М. Мартосенко, А. Нагорна, Ю. Наливайко, Л. Поліщук, А. Скрипченко займалися проблемами експертизи швейних та трикотажних товарів. Н. Аннєнкова здійснювала експертизу якості шкільних зошитів. В. Давидова, Н. Лисенко проводили експертну оцінку виробів косметичних для макіяжу. О. Жолдак аналізував критерії оцінювання якості книжкових видань. О. Передрій вивчала особливості експертизи якості книжкових видань, старовинних книг, ідентифікаційної експертизи монет [8]. Товарознавчі експертні дослідження засобів для догляду за волоссям проводили Н. Луців, В. Гавришко, I. Сторчак, М. Сабор. А. Тернова, С. Сіренко вивчали проблеми товарознавчої експертизи кулькових ручок. При цьому питання експертизи механічних олівців практично не висвітлені.

Основною метою статті $\epsilon$ опис і застосування запропонованої процедури товарознавчої експертизи механічних олівців.

Об'єкт дослідження - механічні олівці, представлені на ринку України.

Методи дослідження. Для експертизи механічних олівців використовували органолептичні, інструментальні й експертні методи.

Виклад основного матеріалу дослідження 3 повним обгрунтуванням отриманих наукових результатів. В структурі роздрібної торгівлі приладдя для письма в Україні значну частку займають механічні олівці, що свідчить про зростаючий попит на них. Оскільки у літературних джерелах відсутні дані про ринок механічних олівців в Україні, у тому числі про експортно-імпортні операції, а також результати їх експертних досліджень, дана проблема викликає значний інтерес.

В Україні механічний олівець став широко поширений порівняно недавно - його поява припала на 90-ті роки 20 століття - одночасно зі становленням українського канцелярського ринку. На відміну від Свропи і США вітчизняний ринок в цьому сегменті поки накопичує потенціал зростання. Вже намітилися явні тенденції до збільшення частки продажу механічних олівців, і незабаром кількість повинна перейти в якість. Олівці, у тому числі механічні, в Україні не виробляються. Ринок на 100 відсотків імпортозалежний. Аналіз структури експорту-імпорту олівців механічних у 2019-2020 роках показав, що у 2019 році експорт товарів, закодованих за УКТ ЗЕД 9608000000 («Ручки кулькові; ручки і 
маркери 3 наконечником 3 повсті та іншого пористого матеріалу; авторучки чорнильні, стилографи та інші авторучки; пера копіювальні; олівці механічні; тримачі для пір'я, тримачі для ручок, тримачі для олівців та подібні»), склав 746,6 тис. дол., 58230,5 кг - за кількістю (6411088,0 штук), імпорт відповідно: 12285,3 тис. дол.; 2536512,2 кг; 256336699,7 штук [9].

Олівців механічних (код за УКТ ЗЕД 9608400000) у 2019 році вивезено на суму 10,9 тис. дол. США у кількості 420,1 кг або 46079,0 штук. Імпорт відповідно складав: 182,7 тис. дол.; 10342,0 кг; 883324,0 штуки [9]. Питома вага олівців механічних у експорті становила всього 1,46 \% - за вартістю; 0,72 - за вагою; 0,72 \% - за кількістю в штуках. По імпорту показники відповідно були наступні 1,$49 ; 0,41 ; 0,34 \%$.

У 2020 році у зв’язку із пандемією показники експорту й імпорту механічних олівців значно зменшились. Експорт склав 7,0 тис. дол.; 320,5 кг; 36986 штук; імпорт відповідно 136 тис. дол.; 6477,1 кг; 460965 штук [10].

Аналіз структури експортно-імпортних операцій з механічними олівцями у 2019-2020 роках за групами країн показав, що у 2019 році показники експорту механічних олівців із країн СНД складав 89,9 \%, а з інших - 10,1. У 2020 році вони становили 90,0 та 10,0 \% відповідно. У 2019 році експорт продукції здійснювався у такі країни СНД, як Російська Федерація, Республіка Молдова, Білорусь. Найбільше відправлялось Російську Федерацію (59,6 \%), Республіку Молдова (18,3 \%) та Білорусь (11,9\%). У 2020 році експорт здійснювався у ті ж країни, але їх частки дещо змінилися: Російська Федерація 64,3%, Білорусь 18,6 \%, Республіка Молдова 7,1 \%. Вся досліджувана продукція надходила в основному з Китаю (74,5 \% у 2019 році та 60,2 - у 2020). У 2019 році механічні олівці надходили також з Японії (10,9%), Німеччини $(5,0)$, Швейцарії $(3,2)$, Словаччини $(1,8)$ та Чехії $(1,5 \%)$. У 2020 році їх також найбільше постачала Японія та Німеччина (18,3 та 10,4 \% відповідно). Таким чином, аналіз експортно-імпортних операцій механічних олівців показує, що Україна здійснює їх реекспорт.

Нами була розроблена процедура здійснення товарознавчої експертизи механічних олівців (рис. 1). Об'єктами товарознавчої експертизи було обрано 5 зразків механічних олівців: зразок № 1 - механічний олівець торгової марки «PILOT»; зразок № 2 - механічний олівець торгової марки «BRAUBERG»; зразок № 3 - механічний олівець торгової марки «ВIC»; зразок № 4 механічний олівець «ЕRICH KRAUSE»; зразок № 5 - механічний олівець «FABER CASTELL». 
Характеристика зразків наведена в табл. 1.

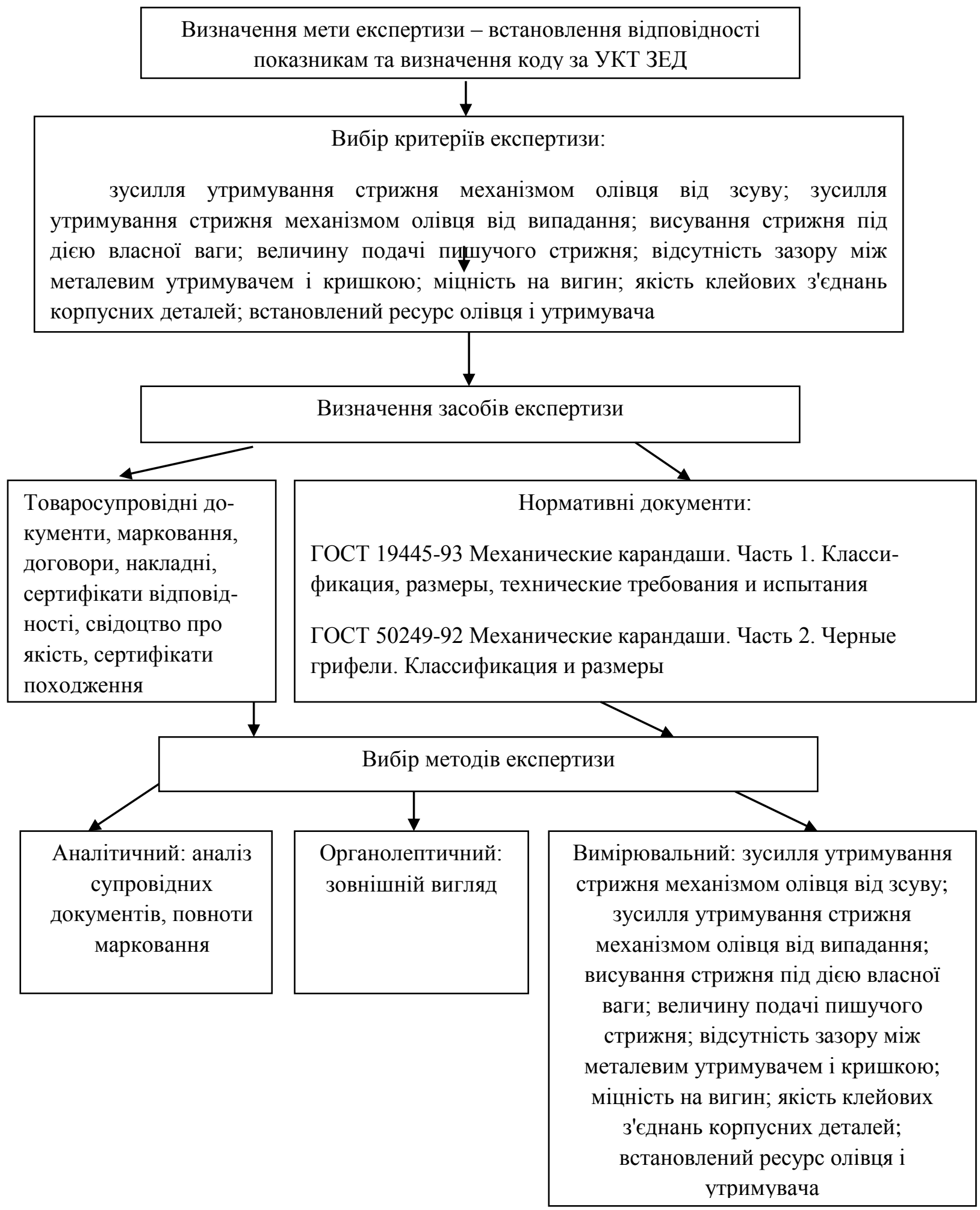

\section{Рис. 1. Етапи проведення товарознавчої експертизи механічних олівців}


Таблиця 1. Характеристика зразків механічних олівців для здійснення експертизи

\begin{tabular}{|c|c|c|}
\hline $\begin{array}{c}\text { № } \\
\text { зразка }\end{array}$ & Назва & Характеристика \\
\hline 1 & $\begin{array}{c}\text { Механічний олівець } \\
\text { «РILOT H-185-B/L } \\
\text { 0,5мм Super Grip» }\end{array}$ & $\begin{array}{l}\text { Артикул: Н-185 } \\
\text { Країна: Японія } \\
\text { Олівець механічний «РILOT Super Grip». Прозорий } \\
\text { пластиковий корпус з гумовим упором для пальців і } \\
\text { металевою цангою, що прибирається. Стрижень 0,5 мм. Колір } \\
\text { корпусу - чорний і синій. }\end{array}$ \\
\hline 2 & $\begin{array}{c}\text { Механічний олівець } \\
\text { «BRAUBERG } \\
\text { «Smart» }\end{array}$ & $\begin{array}{l}\text { Артикул: } 180462 \\
\text { Країна: Німеччина } \\
\text { Олівець механічний «BRAUBERG «Smart». } \\
\text { Корпус виконаний із глянцевого пластика синього кольору. } \\
\text { Корпус сірий, металевий утримувач, ластик, } 0,5 \text { мм, в блістері } \\
\text { з європідвісом. } \\
\text { Олівець з натискним механізмом і зручним упором з } \\
\text { гумовими вставками, який виключає ковзання пальців під час } \\
\text { писання. Цанга «забирається» всередину корпусу. Олівець } \\
\text { заправлений грифелем і оснащений ластиком. }\end{array}$ \\
\hline 3 & $\begin{array}{l}\text { Механічний олівець } \\
\text { «BIC Matic Classic» }\end{array}$ & $\begin{array}{l}\text { Країна: Франція } \\
\text { Олівець механічний «ВIC Matic Classic» з пластиковим } \\
\text { корпусом кольору асорті, прогумований грип, корпус } \\
\text { укомплектований 3-ма стрижнями, } 0.7 \text { мм, з гумкою під } \\
\text { кнопкою. }\end{array}$ \\
\hline 4 & $\begin{array}{c}\text { Механічний олівець } \\
\text { «ERICH } \\
\text { KRAUSE» }\end{array}$ & $\begin{array}{l}\text { Країна: Китай. } \\
\text { Олівець механічний «ERICH KRAUSE «Megapolis Concept», } \\
0,5 \text { мм. } \\
\text { Олівець з натискним механізмом і захистом грифеля від } \\
\text { поломки. Гумовий упор для пальців. Колір пластикового } \\
\text { корпусу чорний. }\end{array}$ \\
\hline 5 & $\begin{array}{c}\text { Механічний олівець } \\
\text { «FABER } \\
\text { CASTELL» }\end{array}$ & $\begin{array}{l}\text { Країна: Німеччина. } \\
\text { Олівець механічний «FABER CASTELL TK® 4600» цанговий } \\
2.0 \text { мм. Корпус пластиковий темно-зелений, В кінцевій } \\
\text { частині олівця вбудована точилка для грифеля. } 11 \text { ступенів } \\
\text { твердості від } 6 \text { Н до 3В }\end{array}$ \\
\hline
\end{tabular}

Перевірку зовнішнього вигляду механічних олівців здійснювали візуально шляхом порівняння із зразками-еталонами. Зовнішній вигляд усіх вибраних зразків олівців відповідав фотографіям в каталозі.

Для визначення зусиль утримання грифеля у робочому стані олівець розміщували вертикально 3 грифелем, висунутим приблизно на 1 мм, 
прикладали вертикально навантаження на стискання 8 Н для номінального діаметра 0,5 мм і більше.

Результати проведених досліджень механічних олівців наведені в табл. 2.

Таблиця 2.Випробування механічних олівців на утримання грифеля у робочому стані

\begin{tabular}{|l|c|c|c|c|c|}
\hline \multicolumn{1}{|c|}{ Торгова марка } & $\begin{array}{c}\text { Країна- } \\
\text { виробник }\end{array}$ & $\begin{array}{c}\text { Діаметр } \\
\text { грифеля, мм }\end{array}$ & $\begin{array}{c}\text { Прикладене } \\
\text { зусилля, } \mathrm{H}\end{array}$ & $\begin{array}{c}\text { Тривалість } \\
\text { прикладання } \\
\text { навантажен-ня, } \\
\text { с }\end{array}$ & Результат \\
\hline PILOT & Японія & 0,5 & 8 & 12 & Нема зміщення \\
\hline BRAUBERG & Німеччина & 0,5 & 8 & 12 & Нема зміщення \\
\hline BIC & Франція & 0,7 & 8 & 10 & Нема зміщення \\
\hline ERICH KRAUSE & Китай & 0,5 & 8 & 12 & Нема зміщення \\
\hline FABER CASTELL & Німеччина & 2,0 & 8 & 11 & Нема зміщення \\
\hline
\end{tabular}

Грифель механічних олівців усіх зразків у робочому стані не зміщувався при писанні при прикладанні навантаження у 8 Н, тобто всі вони відповідають вимогам стандарту.

Перевірку висунення грифеля за один хід механізму висунення механічних олівців типів F i S проводили шляхом вимірювання величини виступання грифеля вимірювальним інструментом - лінійкою.

Було отримано такі результати: виступання грифеля механічного олівця в робочому стані: «PILOT»- 0,7 мм, «BRAUBERG» - 0,6, «ERICH KRAUSE»0,9, «BIC»-0,7, «FABER CASTELL»-2,2 мм (табл. 3).

Таблиця 3. Випробування механічних олівців на виступання грифеля у робочому і неробочому станах

\begin{tabular}{|c|c|c|c|c|c|c|}
\hline \multirow{3}{*}{ Торгова марка } & \multirow{3}{*}{$\begin{array}{c}\text { Діаметр } \\
\text { грифеля, } \\
\text { мм }\end{array}$} & \multicolumn{4}{|c|}{ Виступання грифеля, мм } & \multirow{3}{*}{$\begin{array}{c}\text { Відповідність ви- } \\
\text { могам ГОСТ } \\
19445-93 \\
\end{array}$} \\
\hline & & \multicolumn{2}{|c|}{ у робочому стані } & \multicolumn{2}{|c|}{ у неробочому стані } & \\
\hline & & факт & за ГОСТ & факт & за ГОСТ & \\
\hline PILOT & 0,5 & 0,7 & не менше 0,5 & 0,0 & 0,0 & відповідає \\
\hline BRAUBERG & 0,5 & 0,6 & не менше 0,5 & 0,0 & 0,0 & відповідає \\
\hline $\mathrm{BIC}$ & 0,7 & 0,9 & не менше 0,7 & 0,0 & 0,0 & відповідає \\
\hline ERICH KRAUSE & 0,5 & 0,7 & не менше 0,5 & 0,0 & 0,0 & відповідає \\
\hline FABER CASTELL & 2,0 & 2,2 & не менше 2,0 & 0,0 & 0,0 & відповідає \\
\hline
\end{tabular}

У всіх механічних олівцях грифель у робочому стані виступав відповідно до вимог стандарту на величину, не меншу діаметра грифеля, а у неробочому не виступав, що також відповідає встановленим вимогам. 
Придатність механічних олівців до використання після падіння перевіряли скиданням зразка з висоти 1 метра на дерев'яну поверхню товщиною 0,03 мм боковою поверхнею. Зовнішній огляд зразків показав, що на всіх олівцях, крім механічного олівця торгової марки «ERICH KRAUSE», не виявлено руйнування. На корпусі олівця «ERICH KRAUSE» було виявлено тріщину (табл. 4).

\section{Таблиця 4. Випробування механічних олівців на їх придатність до використання після падіння}

\begin{tabular}{|l|c|c|c|}
\hline \multicolumn{1}{|c|}{ Торгова марка } & Діаметр грифеля, мм & $\begin{array}{c}\text { Наявність сколів, } \\
\text { тріщин }\end{array}$ & $\begin{array}{c}\text { Відповідність } \\
\text { вимогам } \\
\text { ГОСТ 19445-93 }\end{array}$ \\
\hline PILOT & 0,5 & нема & відповідає \\
\hline BRAUBERG & 0,5 & нема & відповідає \\
\hline BIC & 0,7 & нема & відповідає \\
\hline ERICH KRAUSE & 0,5 & тріщина корпусу & не відповідає \\
\hline FABER CASTELL & 2,0 & нема & відповідає \\
\hline
\end{tabular}

Міцність механічних олівців на вигин перевіряли на стенді, який забезпечував прикладання до олівця статичного навантаження $50 \mathrm{H}$ у місцях з'єднань. Навантаження тривало від 10 до 15 с. Міцність на вигин, за стандартом, має бути не менше $50 \mathrm{H}$.

Для проведення даного дослідження було виготовлено пристрій, що мав наступний вигляд: дві рухомі стійки, що мають зручні майданчики для розміщення олівця (майданчики знаходяться на нерухомій лінійці). Пристрій, який мав масу 0,076 кг, був встановлений у центрі майданчика товарних ваг. На ньому розміщувалися досліджувані зразки. Зусилля було прикладене у місцях з'єднання частин механічних олівців величиною у $50 \mathrm{H}$.

Результати випробувань наведені в табл. 5.

\section{Таблиця 5. Випробування механічних олівців щодо міцності на вигин у} місцях з'єднання

\begin{tabular}{|l|c|c|c|}
\hline \multicolumn{1}{|c|}{ Торгова марка } & $\begin{array}{c}\text { Прикладене } \\
\text { зусилля, } \mathrm{H}\end{array}$ & $\begin{array}{c}\text { Тривалість прикладання } \\
\text { навантаження, с }\end{array}$ & $\begin{array}{c}\text { Відповідність вимогам } \\
\text { ГОСТ 19445-93 }\end{array}$ \\
\hline PILOT & 50 & 11 & відповідає \\
\hline BRAUBERG & 50 & 10 & відповідає \\
\hline BIC & 50 & 11 & відповідає \\
\hline ERICH KRAUSE & 50 & 14 & не відповідає \\
\hline FABER CASTELL & 50 & 13 & відповідає \\
\hline
\end{tabular}


Якість з'єднань корпусних деталей перевіряли на приладах, що забезпечують прикладання до випробовуваних складальних одиниць статичного осьового зусилля $(50 \pm 0,5) \mathrm{H}$ і крутного моменту $(1,0 \pm 0,1) \mathrm{H} \bullet$ м, при цьому не повинно спостерігатися зміщення деталей відносно одна одної.

Тривалість прикладення зусилля - від 10 до 15 с. Результати проведених випробувань наведені у табл. 6.

Таблиця 6. Випробування механічних олівців щодо якості з'сднань корпусних деталей

\begin{tabular}{|c|c|c|c|c|c|}
\hline Торгова марка & $\begin{array}{l}\text { Країна- } \\
\text { виробник }\end{array}$ & $\begin{array}{c}\text { Діаметр } \\
\text { грифеля, мм }\end{array}$ & $\begin{array}{c}\text { Прикладене } \\
\text { зусилля, Н }\end{array}$ & $\begin{array}{c}\text { Тривалість } \\
\text { прикладання } \\
\text { навантаження, с }\end{array}$ & Результат \\
\hline PILOT & Японія & 0,5 & 50 & 12 & Нема зміщень \\
\hline BRAUBERG & Німеччина & 0,5 & 50 & 12 & Нема зміщень \\
\hline$\overline{B I C}$ & Франція & 0,7 & 50 & 10 & Нема зміщень \\
\hline ERICH KRAUSE & Китай & 0,5 & 50 & 12 & Нема зміщень \\
\hline FABER CASTELL & Німеччина & 2,0 & 50 & 11 & Нема зміщень \\
\hline
\end{tabular}

Зміщення деталей відносно одна одної у всіх зразках механічних олівців не було.

Гамма-процентний ресурс утримувача перевіряли на стенді, що забезпечує відгин утримувача на величину $(2,5 \pm 0,5)$ мм 3 частотою $(60 \pm 5)$ відгинів в хвилину. Результати досліджень наведені в табл. 7.

Таблиця 7. Випробування механічних олівців щодо визначення гаммапроцентного ресурсу

\begin{tabular}{|l|l|c|c|c|c|}
\hline \multicolumn{1}{|c|}{ Торгова марка } & $\begin{array}{c}\text { Країна- } \\
\text { виробник }\end{array}$ & $\begin{array}{c}\text { Діаметр } \\
\text { грифеля, мм }\end{array}$ & $\begin{array}{c}\text { Відгин } \\
\text { утримувача, } \\
\text { мм }\end{array}$ & $\begin{array}{c}\text { Частота } \\
\text { відгинів, } \\
\text { відгинів/хв. }\end{array}$ & $\begin{array}{c}\text { Гамма- } \\
\text { процентний } \\
\text { ресурс, відгинів }\end{array}$ \\
\hline PILOT & Японія & 0,5 & 50 & 12 & 1780 \\
\hline BRAUBERG & Німеччина & 0,5 & 50 & 12 & 1750 \\
\hline BIC & Франція & 0,7 & 50 & 10 & 1800 \\
\hline ERICH KRAUSE & Китай & 0,5 & 50 & 12 & 1720 \\
\hline FABER CASTELL & Німеччина & 2,0 & 50 & 11 & 1770 \\
\hline
\end{tabular}

Проведені дослідження виявили, що найбільший гамма-процентний ресурс мають механічні олівці торгової марки ВІC - 1800 відгинів, далі в міру 
зменшення: PILOT - 1780, FABER CASTELL - 1770, BRAUBERG - 1750, ERICH KRAUSE - 1720 відгинів.

\section{Висновки та перспективи подальших досліджень. Результати} проведених досліджень свідчать, що механічні олівці торгових марок PILOT, BRAUBERG, BIC, FABER CASTELL відповідали встановленим у ГОСТ 1944593 [10] вимогам, а олівці марки ERICH KRAUSE китайського виробництва за двома показниками (міцність на вигин та придатність до використання після падіння) не відповідають їм.

\section{Список використаних джерел}

1. Байдакова Л.І., Ягелюк С.В. Комплексна блок-схема проведення експертизи якості непродовольчих товарів. Актуальні проблеми теорії $і$ практики експертизи товарів : матеріали I міжнар. наук. практ. інтернет-конф., м. Полтава, 18-20 берез. 2014 р. Полтава, 2014. C. 11-13.

2. Зубков М.О., Янченко Н.В. Експертні методи товарної експертизи. Актуальні проблеми теорії і практики експертизи товарів : матеріали VII Міжнар. наук.-практ. інтернет-конф., м. Полтава, 2-3 квіт. 2020 р. Полтава, 2020. С. 25-28.

3. Мохненко А.С. Інформаційне забезпечення експертизи товарів. Актуальні проблеми теорії і практики експертизи товарів : матеріали VII Міжнар. наук.-практ. інтернет-конф., м. Полтава, 2-3 квіт. 2020 р. Полтава, 2020. С. 35-37.

4. Осипенко Н.I., Писаренко Т.П. Проблеми експертної діяльності в сучасних умовах. Актуальні проблеми теорії і практики експертизи товарів : матеріали I міжнар. наук. практ. інтернет-конф., м. Полтава, 18-20 берез. 2014 р. Полтава, 2014. С. 34-35.

5. Тернова А.С., Сіренко С.О. Товарознавча експертиза кулькових ручок. Актуальні проблеми теорії і практики експертизи товарів : матеріали V Міжнар. наук.-практ. інтернетконф., м. Полтава, 20-22 берез. 2017 р. Полтава, 2017. С. 378-382.

6. Хлєбнікова Н.Б. Застосування експертних методів у дослідженні непродовольчих товарів. Актуальні проблеми теорії і практики експертизи товарів : матеріали I міжнар. наук. практ. інтернет-конф., м. Полтава, 18-20 берез. 2014 р. Полтава, 2014. С. 48-50.

7. Ющенко Ю.В. Інформаційно-аналітичні засоби експертизи товарів. Актуальні проблеми теорії і практики експертизи товарів : матеріали VII Міжнар. наук.-практ. інтернет-конф., м. Полтава, 2-3 квіт. 2020 р. Полтава, 2020. С. 61-65.

8. Передрій О.І. Особливості ідентифікаційної експертизи монет при їх переміщенні через митний кордон України. Товарознавчий вісник. 2016. Випуск 9. С. 53-60.

9. Експорт-імпорт окремих видів товарів за країнами світу за 2019 рік. URL: http://www.ukrstat.gov.ua/operativ/operativ2019/zd/e_iovt/arh_iovt2019.htm

10. Експорт-імпорт окремих видів товарів за країнами світу за 2020 рік. URL: http://www.ukrstat.gov.ua/operativ/operativ2020/zd/e_iovt/arh_iovt2020.htm

11. ГОСТ 19445-93. Механические карандаши. Часть 1. Классификация, размеры, 
технические требования и испытания. [Действующий с 1993-01-01]. Изд. офиц. Москва : ИПК Издательство стандартов, 1995. 16 с.

\section{References}

1. Baidakova, L.I. \& Yaheliuk, S.V. (2014). Kompleksna blok-skhema provedennia ekspertyzy yakosti neprodovolchykh tovariv [Comprehensive block diagram of the examination of the quality of nonfood products]. Aktualni problemy teorii i praktyky ekspertyzy tovariv [Current problems of theory and practice of examination of goods] : materialy I mizhnar. nauk. prakt. internet-konf., 18-20 berez. 2014, Poltava, 11-13.

2. Zubkov, M.O. \& Yanchenko, N.V. (2020). Ekspertni metody tovarnoi ekspertyzy [Expert methods of commodity examination]. Aktualni problemy teorii i praktyky ekspertyzy tovariv [Current problems of theory and practice of examination of goods] : materialy VII Mizhnar. nauk.-prakt. internet-konf., 2-3 kvit. 2020, Poltava, 25-28.

3. Mokhnenko, A.S. (2020). Informatsiine zabezpechennia ekspertyzy tovariv [Information support of examination of goods]. Aktualni problemy teorii i praktyky ekspertyzy tovariv [Current problems of theory and practice of examination of goods] : materialy VII Mizhnar. nauk.-prakt. internet-konf., 2-3 kvit. 2020, Poltava, 35-37.

4. Osypenko, N.I. \& Pysarenko, T.P. (2014). Problemy ekspertnoi diialnosti v suchasnykh umovakh [Problems of expert activity in modern conditions]. Aktualni problemy teorii i praktyky ekspertyzy tovariv [Current problems of theory and practice of examination of goods] : materialy I mizhnar. nauk. prakt. internet-konf., 18-20 berez. 2014, Poltava, 34-35.

5. Ternova, A.S. \& Sirenko, S.O. (2017). Tovaroznavcha ekspertyza kulkovykh ruchok [Commodity examination of ballpoint pens]. Aktualni problemy teorii i praktyky ekspertyzy tovariv [Current problems of theory and practice of examination of goods] : materialy V Mizhnar. nauk.-prakt. internet-konf., 20-22 berez. 2017, Poltava, 378-382.

6. Khliebnikova, N.B. (2014). Zastosuvannia ekspertnykh metodiv u doslidzhenni neprodovolchykh tovariv [Application of expert methods in the study of non-food products]. Aktualni problemy teorii $\mathrm{i}$ praktyky ekspertyzy tovariv [Current problems of theory and practice of examination of goods] : materialy I mizhnar. nauk. prakt. internet-konf., 18-20 berez. 2014, Poltava, 48-50.

7. Iushchenko, Yu.V. (2020). Informatsiino-analitychni zasoby ekspertyzy tovariv [Information and analytical means of examination of goods]. Aktualni problemy teorii i praktyky ekspertyzy tovariv [Current problems of theory and practice of examination of goods] : materialy VII Mizhnar. nauk.-prakt. internetkonf., 2-3 kvit. 2020, Poltava, 61-65.

8. Peredriy O. (2016). Osoblyvosti identyfikatsiinoi ekspertyzy monet pry yikh peremishchenni cherez mytnyi kordon Ukrainy. [Features of identification examination of coins during their movement across the customs border of Ukraine]. Tovaroznavchyi visnyk [Commodity Bulletin]. 2016. Issue 9. pp. 53-60.

9. Eksport-import okremykh vydiv tovariv za krainamy svitu za 2019 rik. [Export-import of certain types of goods by countries of the world for 2019] Retrieved from http://www.ukrstat.gov.ua/operativ /operativ2019/zd/e_iovt/arh_iovt2019.htm

10. Eksport-import okremykh vydiv tovariv za krainamy svitu za 2020 rik. [Export-import of certain types of goods by countries of the world for 2020] Retrieved from http://www.ukrstat.gov.ua/operativ /operativ2020/zd/e_iovt/arh_iovt2020.htm

11. Mekhanycheskye karandashy. Chast 1 . Klassyfykatsyia, razmerd, tekhnycheskye trebovanyia y ysputanyia, [Mechanical pencils. Part 1. Classification, dimensions, specifications and tests] 16 GOST 19445-93 (1995) 
Goal. The development of a procedure for conducting a commodity examination of mechanical pencils.

Methodology. For the examination of mechanical pencils, there were used the organoleptic, instrumental and expert methods.

Results. An analysis of export-import operations of mechanical pencils shows that Ukraine is doing their re-export: in 2019-2020, most of these goods were sent to such CIS countries as the Russian Federation (59, 6 and 64, 3\%, according to the years), the Republic of Moldova (18 3 and 18, 6\%), Belarus (11, 9 and 7, 1\%). All research products came mainly from China (74, 5\% in 2019 and 60, 2\% in 2020). In 2019, mechanical pencils also came from Japan (10, 9\%), Germany (5,0), Switzerland (3,2), Slovakia (1,8) and the Czech Republic (1,5\%). In 2020, Japan and Germany also supplied more of them (18,3 and 10,4\% conformably). The procedure for conducting a commodity examination of mechanical pencils included such stages as determining of the goal, choosing the criteria, determining the means and choosing the methods. The objects of the commodity examination were five samples of mechanical pencils of the most common trademarks: sample no. 1 is mechanical pencil of the PILOT trademark; sample no. 2 - mechanical pencil of the BRAUBERG trademark; sample no. 3 - mechanical pencil of the BIC trademark; sample no. 4 mechanical pencil ERICH KRAUSE; sample no. 5 - mechanical pencil FABER CASTELL.

In accordance with the tasks, the following indicators were explored: organoleptic (outward appearance) and mechanical (the effort of holding the rod by the pencil mechanism against shear; efforts to hold the rod by the pencil mechanism from falling out; the extension of the rod under its own weight; the amount of feed of the writing rod, the absence of a gap between the metal holder and cover; bending strength, quality of glue joints of body parts; fixed resource of pencil and holder). All investigated quality indicators of mechanical pencil samples comply with the established standards.

Scientific novelty. A procedure has been developed for conducting a commodity examination of mechanical pencils.

The practical significance of the research results lies in the development of criteria, means and methods of commodity examination of mechanical pencils that can be used in the work of enterprises.

Key words: pencil, mechanical pencils, export-import operations, re-export, expertise, commodity examination, procedure, criteria, means and methods of commodity examination.

Стаття рекомендована до друку доктором технічних наук, професором Байдаковою Л.І. Дата надходженняв редакиію 05.01.2021 р. 